\title{
PELATIHAN DAN PENDAMPINGAN WIRAUSAHA MUDA DI UNIVERSITAS MULAWARMAN
}

\author{
Jawatir Pardosi'1), Rudi Agung Nugroho²), Rita Mariati ${ }^{3)}$, Julinda R. Manullang ${ }^{3)}$ \\ 1)Fakultas keguruan dan IImu pendidikans Mulawarman, Samarinda, Kalimantan Timur, Indonesia \\ ${ }^{2)}$ Fakultas Matematika dan IImu Pengetahuan Alam, Universitas Mulawarman, Samarinda, Kalimantan Timur, Indonesia \\ ${ }^{3)}$ Fakultas Pertanian, Universitas Mulawarman, Samarinda, Kalimantan Timur, Indonesia \\ Corresponding author : Julinda R.manullang \\ E-mail : julindamanullang@yahoo.com
}

Diterima 30 Oktober 2021, Disetujui 02 November 2021

\begin{abstract}
ABSTRAK
Berbagai metode terus dilakukan dan digalakkan untuk menumbuhkan dan mengembangkan semangat berwirausaha di Universitas Mulawarman sehingga mahasiswa semakin tertarik untuk berwirausaha. Tujuan dari kegiatan Program Pengembangan Kewirausahaan (PPK) ini adalah untuk mengembangkan kewirausahaan di Universitas Mulawarman yang berorientasi dari keilmuan dan potensi lokal sehingga menghasilkan wirausaha yang handal, mandiri dan professional. Dalam pencapaian target tersebut program PPK pada tahun ke tiga ini diawali dengan melakukan kegiatan webinar yang menghadirkan narasumber dari Bank Indonesia, dosen Universitas Mulawarman dan startup serta peserta PPK yang sudah mandiri. Kegiatan webinar dilaksanakan juga merupakan dari proses sosialisasi PPK dan sekaligus menjaring peserta mahasiswa/alumni Universitas Mulawarman yang berminat untuk mendaftar. Sosialisasi ke fakultas juga Jurusan/program Studi dan sampai akhir pendaftaran sebanyak 55 orang mahasiswa/alumni mendaftar dari berbagai fakultas di Universitas Mulawarman Seleksi tenant dilakukan secara transparan dengan wawancara melalui video call. Penetapan calon tenant sejumlah dua puluh orang yang lolos seleksi dari berbagai fakultas. Pelaksanaan pelatihan kewirausahaan melalui offline/online teori dan praktek. Kunjungan lapang dilakukan ke wirausaha UMKM yang sudah maju, pendampingan secara kontiniu dan magang wirausaha Dilakukan juga presentasi proposal bisnis untuk mengetahui sampai sejauh mana peserta PPK mampu menyusun proposal bisnis.
\end{abstract}

Kata kunci: magang; pelatihan; pendampingan; PPK; universitas mulawarman

\begin{abstract}
Various methods continue to be carried out and are encouraged to grow and develop the spirit of entrepreneurship at Mulawarman University so that students are increasingly interested in entrepreneurship. The purpose of this Entrepreneurship Development Program (PPK) activity is to develop entrepreneurship at Mulawarman University which is oriented from local knowledge and potential so as to produce reliable, independent and professional entrepreneurs. In achieving this target, the PPK program in its third year was initiated by conducting a webinar that presented resource persons from Bank Indonesia, Mulawarman University lecturers and startups as well as independent PPK participants. The webinar activity carried out is also part of the PPK socialization process and at the same time attracts Mulawarman University student/alumni participants who are interested in registering. Socialization to faculties as well as Departments/Study programs and until the end of registration as many as 55 students/alumni enrolled from various faculties at Mulawarman University. Tenant selection is carried out transparently by interview via video call. Determination of prospective tenants as many as twenty people who passed the selection from various faculties. Implementation of entrepreneurship training through offline/online theory and practice. Field visits were conducted to advanced MSME entrepreneurs, continuous mentoring and entrepreneurial internships. Business proposal presentations were also conducted to find out to what extent KDP participants were able to develop business proposals.
\end{abstract}

Keywords : internship; trainin; mentoring; PPK; mulawarman university

\section{PENDAHULUAN}

"Kewirausahaan adalah suatu cara berpikir, menelaah, dan bertindak yang didasarkan pada peluang bisnis, pendekatan holistik, dan kepemimpinan yang seimbang" (Timmons \&
Spinelli, 2004: 31). roses kewirausahaan menuntut kemauan untuk mengambil resiko dengan penuh perhitungan sehingga dapat mengatasi rintangan untuk mencapai kesuksesan yang diharapkan. Pada umumnya, 
wirausahawan menggunakan kecerdikannya untuk memanfaatkan sumberdaya yang terbatas. Kewirausahaan dapat diajarkan melalui pendidikan dan pelatihan. "... entrepreneurship has models, processes, and case studies that allow the topic to be studied and the knowledge to be acquired" (Kuratko \& Hodgetts, 2007: 34). Menurut Alma (2010: 12) yang paling mendorong seseorang untuk memasuki karir wirausaha adalah adanya (1) personal attributes dan (2) personal environment. Hasil-hasil penelitian menyebutkan bahwa minat berwirausaha dipengaruhi oleh potensi kepribadian wirausaha dan lingkungan.

$$
\text { Pada tahun } 2005 \text { Universitas }
$$

Mulawarman telah mengembangkan kewirausahaan pada semua fakultas melalui Mata Kuliah Kewirausahaan sebagai mata kuliah WAJIB di setiap fakultas yang bertujuan untuk mensukseskan program pemerintah untuk lahirnya wirausaha baru yang mandiri, inovatif dan trampil. Persentase alumni yang berwirausaha hanya $0.57 \%$ dari seluruh alumni bahkan jumlah peserta yang lolos untuk pemberian bantuan modal usaha hanya separuhnya setiap tahunnya sedangkan untuk pengajuan proposal PMW dan KBMI tahun 2017 Universitas Mulawarman hanya mampu meloloskan 2 proposal saja sedangkan thn 2018 tidak ada yang lolos untuk proposal KBMI, begitu pun untuk program PKM K mahasiswa Univeristas Mulawarman hanya mampu meloloskan 1-2 proposal saja setiap tahunnya. Penyebabnya adalah kurangnya pengetahuan untuk menyusun proposal yang baik berbasis kewirausahaan dan minimnya kreativitas dan inovasi dan keterbaharuan yang berbasis pada bidang keilmuan (program studi). Kenyataan diatas tentu menjadi tantangan bagi Universitas Mulawarman dalam melahirkan wirausaha muda dari kampus untuk mensukseskan program Pemerintah.

Menurut Haeruman (2000), tantangan bagi dunia usaha, terutama pengembangan UKM, mencakup aspek yang luas, antara lain :Peningkatan kualitas SDM dalam hal kemampuan manajemen, organisasi dan teknologi, Kompetensi kewirausahaan, Akses yang lebih luas terhadap permodalan, Informasi pasar yang transparan, Faktor input produksi lainnya, dan Iklim usaha yang sehat yang mendukung inovasi, kewirausahaan dan praktek bisnis serta persaingan yang sehat

Berdasarkan data bahwa potensi dan nilai ekonomi produk mahasiswa PKM usaha mahasiswa melalui PKM K dan PMW pada produk busana, minuman dan produk tersebut cenderung belum berbasis keahlian/program studi. Produk PKM yang sudah dirintis melalui proposal cenderung tidak berbasis keilmuan mahasiswa. Setelah program PKMK selesai dilaksanakan cenderung mahasiswa tidak melanjutkan ataupun mengembangkan menjadi produk unggulan usaha. Hal ini disebabkan kurangnya kreativitas dan motivasi mahasiswa untuk terus menekuni produk yang berasal dari program PKM K.

Pembuatan proposal untuk pengajuan pendanaan ke lembaga keuangan juga sering tidak terfasilitasi. Hal ini bisa disebabkan karena belum mahir nya menyusun proposal yang berorientasi bisnis serta produk mahasiswa belum memiliki keterbaharuan ataupun keunggulan karena produk yang sejenis juga banyak beredar di pasaran. Saat ini produk yang dihasilkan dan dapat diterima oleh pasar cenderung memiliki ke khas an ataupun keunikan yang nantinya dapat menarik konsumen untuk membeli.

.Hasil penelitian Imron Rosyadi(2013) menyatakan salah satu yang menjadi kendala dalam Usaha mikro dan kecil milik mahasiswa adalah manajemen usaha yang bersifat historically transmitted, sehingga menghambat perkembangan usaha (kasus untuk jenis usaha tertentu); dan Skill kewirausahaan yang relatif masih rendah, sehingga usaha tidak berkembang secara optimal.

Berdasarkan hasil tracer study yang dilakukan sebenarnya alumni sangat berminat untuk menjadi wirausaha hanya terkendala pada kurangnya skill dan wawasan untuk bisa sukses menjadi wirausaha, motivasi yang rendah pada alumni serta sulitnya mendapatkan bantuan pendanaan untuk mengembangkan wirausaha secara mandiri.

Berdasarkan permasalahan diatas maka solusi yang dapat dilakukan adalah mengikutsertakan mahasiswa/alumni Universitas Mulawarman dalam kegiatan Program Pengembangan Kewiraushaan (PPK) yang dilakukan dengan tahapan pelatihan, studi lapang UMKM , pendampingan dan magang wirausaha

Tujuan kegiatan ini adalah menambah jumlah mahasiswa/alumni menjadi wirausaha muda yang inovatif dan terampil, meningkatkan skill dan keterampilan wirausaha muda di Universitas mulawarman.

\section{METODE}

Metode yang dilaksanakan pada kegiatan PPK tahun 2021 adalah dengan memberikan pendidikan melalui pelatihan untuk menambahn wawasan serta motivasi wirausaha, serta memberikan pendampingan/pembimbingan secara kontinu bagi mahasiswa dan alumni sampai pada tahap pengembangan produk agar menjadi produk 
yang memiliki nilai jual dan pemasaran untuk dapat menjadi usaha/bisnis yang memberikan nilai ekonomi melalui program PPK ini. Pada kegiatan bekerjasama atau bermitra dengan Mini University Bank Indonesia Provinsi Kalimantan Timur serta lembaga lainnya seperti UMKM untuk tempat studi lapang dan magang usaha. Adapun tahapan metode yang dilakukan adalah :

\section{A. Sosialisasi melalui Webinar}

Sosialisasi kegiatan PPK pada tahun 2021 diawali dengan kegiatan Webinar pada bulan Juni dengan tema "Membangun Wirausaha Muda dan Bisnis Startup di Era New Normal" menghadirkan narasumber dari Bank Indonesia prov. Kalimantan Timur yaitu Aswin Gantina dan juga menghadir kan narasumber Dr Gusti Noorlitaria Achmad, Septian Suryo (startup) dan Badariah Anugrah Sukma Wardani,S.Pt (wirausaha mandiri dari PPK 2020) yang menyampaikan sukses story sebagai wirausaha hidroponik di samarinda . Kegiatan webinar ini juga menjadi salah satu metode untuk memberi kesempatan kepada para mahasiswa/alumni Universitas Mulawarman untuk mendaftar sebagai peserta program PPK.

\section{B. Rekruitmen Tenant}

Pada bulan Mei dilaksanakan pendaftaran calon tenant dengan mengisi form pendaftaran secara online yang sudah disiapkan oleh tim PPK Pada akhir pendaftaran maka terdapat 55 orang mahasiswa/alumni yang telah mendaftar dari berbagai fakultas dengan berbagai bidang usaha. Form pendaftaran

a. Seleksi wawancara online via video call Whatsapp Setelah dilakukan pendaftaran diterima tenant dengan jumlah 20 orang yang terdiri dari FKIP 5 orang, FK 3 orang, FTeknik 3 orang, FAPERTA 6 orang, FAHUT 2 orang, FISIPOL 1 orang yang terdiri dari mahasiswa dan alumni Universitas Mulawarman, dengan nama peserta sebagai berikut

Proses penetapan calon tenant dilakukan setelah melakukan seleksi wawancara online via video call WhatsApp yang dilakukan oleh tim PPK. Berdasarkan test tersebut terseleksi 20 orang mahasiswa yang akan mengikuti kegiatan PPK selanjutnya. Untuk mengikuti program PPK dengan criteria pernah merintis usaha baru dan usaha yang sedang dijalankan .

b. Penetapan Tenant PPK
Metode pendekatan meliputi sebagai berikut :

\section{Pelaksanaan pelatihan Kewirausahaan secara offline dan online}

Sampai saat ini pandemi Covid 19 di Negara Indonesia begitu juga di Kalimantan Timur khususnya kota Samarinda sejak tahun 2020 belum berakhir dan sejak Juni 2021 mengalami peningkatan pesan kasus yang terpapar. Sehingga mengharuskan kita mengikuti himbauan pemerintah bekerja dirumah dengan mengurangi mobilitas serta ikuti 5 M. Sedangkan sejak bulan juni sudah diberlakukan PPKM level 4 di kota Samarinda yang artinya bisa beraktifitas diluar rumah/kampus tapi tetap mengikuti protokol Covid 19 yang sangat ketat.

Kondisi tersebut di atas maka dilakukan pelatihan secara offline dan online yang diikuti seluruh peserta sejumlah 20 orang dengan tujuan untuk menumbuhkan dan semangat berwirausaha sehingga memiliki mental yang siap untuk berwirausaha, selanjutnya peningkatan kreativitas untuk menghasilkan produk yang berbasis ilmu pengetahuan/kemampuan akademik nya untuk menjadi produk yang memiliki nilai ekonomis/komersial serta keterbaharuan dalam produk.

Selanjutnya kemampuan dalam pemasaran produk secara onlione/offline melalui digital marketing untuk mampu menghadapi persaingan dalam wirausaha, pelatihan juga dilakukan untuk penentuan harga jual (HPP), foto produk serta pembuatan proposal bisnis tenant serta penyusunan laporan keuangan serta untuk pengembangan usaha.

Kondisi pandemi covid19 yang akhirnya pemberlakuan PPKM level 4 pelatihan dilakukan secara online dan offline dengan mengikuti protokol kesehatan dan peraturan yang berlaku di Universitas Mulawarman. Materi pelatihan ( teori dan praktek ) meliputi :

1. Visi dan misi wirausaha

2. Spirit Leadership

3. Segmentasi pasar

4. Added value

5. HPP dan Financial Literasi

6. Bussines Road Map

7. Branding

8. Foto Produk

9. Digital marketing

10. Kewirausahaan berbasis perguruan tinggi

11. Teknik penyusunan proposal bisnis kemendikbudristek

12. Teknik penyusunan proposal bisnis ke investor 
13. Presentasi proposal bisnis

HASIL DAN PEMBAHASAN

Dampak ekonomi dan sosial kegiatan PPK

Tabel 1. Dampak Ekonomi dan Sosial

\begin{tabular}{|c|c|c|c|}
\hline \multicolumn{4}{|c|}{ Kegiatan PPK } \\
\hline NO & $\begin{array}{c}\text { Kegiata } \\
\mathbf{n}\end{array}$ & $\begin{array}{c}\text { Sebelum } \\
\text { kegiatan } \\
\text { PPK } \\
\end{array}$ & $\begin{array}{l}\text { Setelah } \\
\text { kegiatan } \\
\text { PPK }\end{array}$ \\
\hline 1 & $\begin{array}{c}\text { Motivasi } \\
\text { bisnis }\end{array}$ & $\begin{array}{l}\text { Motivasi dari } \\
\text { peserta } \\
\text { belum kuat }\end{array}$ & $\begin{array}{l}\text { Pada } \\
\text { pelatihan } \\
\text { diberikan } \\
\text { semangat } \\
\text { untuk } \\
\text { menumbuh } \\
\text { kan spirit } \\
\text { dan } \\
\text { motivasi } \\
\text { serta jiwa } \\
\text { wirausaha } \\
\end{array}$ \\
\hline 2 & Tenant & $\begin{array}{c}\text { Rencana } \\
\text { bisnis belum } \\
\text { tersusun }\end{array}$ & $\begin{array}{l}\text { Rencana } \\
\text { bisnis mulai } \\
\text { tersusun } \\
\text { rapi dengan } \\
\text { pembuatan } \\
\text { segmentasi } \\
\text { dan BMC } \\
\text { yang di } \\
\text { lakukan } \\
\text { dalam } \\
\text { pelatihan }\end{array}$ \\
\hline 3. & $\begin{array}{c}\text { Promosi } \\
\text { produk } \\
\text { usaha }\end{array}$ & $\begin{array}{l}\text { Promosi } \\
\text { masih belum } \\
\text { dilakukan }\end{array}$ & $\begin{array}{l}\text { Promosi } \\
\text { yang dibuat } \\
\text { mulai } \\
\text { menjadi } \\
\text { lebih efektif } \\
\text { dan lebih } \\
\text { pas dengan } \\
\text { target pasar } \\
\text { yang dituju } \\
\text { yang } \\
\text { diajarkan } \\
\text { selama } \\
\text { pelatihan } \\
\text { melalui } \\
\text { online } \\
\text { (media } \\
\text { social) }\end{array}$ \\
\hline 4. & Produk & $\begin{array}{l}\text { Produk } \\
\text { masih } \\
\text { sederhana } \\
\text { dan ada } \\
\text { yang belum } \\
\text { memiliki } \\
\text { produk tapi } \\
\text { sudah } \\
\text { merintis }\end{array}$ & $\begin{array}{l}\text { Sudah } \\
\text { mulai } \\
\text { memikirkan } \\
\text { untuk } \\
\text { membuat } \\
\text { inovasi } \\
\text { produk dan } \\
\text { sudah mulai } \\
\text { membentuk } \\
\text { produk } \\
\text { yang belum } \\
\text { dijalankan }\end{array}$ \\
\hline
\end{tabular}

\begin{tabular}{|c|c|c|c|}
\hline & & & $\begin{array}{l}\text { dengan } \\
\text { ajaran yang } \\
\text { dilakukan } \\
\text { selama } \\
\text { pelatihan }\end{array}$ \\
\hline 5 & HPP & $\begin{array}{l}\text { Belum mahir } \\
\text { untuk } \\
\text { menghitung } \\
\text { HPP produk }\end{array}$ & $\begin{array}{l}\text { Melalui } \\
\text { pelatihan } \\
\text { HPP maka } \\
\text { sudah } \\
\text { mampu } \\
\text { untuk } \\
\text { menentuka } \\
\text { n HPP } \\
\text { produk } \\
\text { usaha }\end{array}$ \\
\hline 6. & $\begin{array}{l}\text { Kualitas } \\
\text { Produk }\end{array}$ & $\begin{array}{l}\text { Kualitas } \\
\text { produk }\end{array}$ & $\begin{array}{l}\text { Produk } \\
\text { sudah } \\
\text { memasuki } \\
\text { laboratoriu } \\
\text { m untuk di } \\
\text { analisa } \\
\text { nutrisi yang } \\
\text { terkandung } \\
\text { di dalamnya }\end{array}$ \\
\hline 7. & $\begin{array}{c}\text { Desain } \\
\text { Kemasa } \\
n \\
\text { Produk }\end{array}$ & $\begin{array}{l}\text { Desain } \\
\text { Kemasan } \\
\text { masih } \\
\text { terbentuk } \\
\text { sederhana } \\
\text { dan } \\
\text { seadanya }\end{array}$ & $\begin{array}{l}\text { Desain } \\
\text { Kemasan } \\
\text { mulai dibuat } \\
\text { dan } \\
\text { diajarkan } \\
\text { menjadi } \\
\text { lebih } \\
\text { menarik } \\
\text { yang } \\
\text { diajarkan } \\
\text { selama } \\
\text { pelatihan }\end{array}$ \\
\hline 8 & $\begin{array}{l}\text { Segme } \\
\text { ntasi } \\
\text { Pasar }\end{array}$ & $\begin{array}{l}\text { Belum } \\
\text { dilakukan }\end{array}$ & $\begin{array}{l}\text { Setelah } \\
\text { pelatihan } \\
\text { sudah } \\
\text { paham } \\
\text { segmentasi } \\
\text { pasar dari } \\
\text { usaha yang } \\
\text { sedang } \\
\text { dirintis/dijal } \\
\text { ankan }\end{array}$ \\
\hline 9. & $\begin{array}{c}\text { Pemasa } \\
\text { ran }\end{array}$ & $\begin{array}{l}\text { Pemasaran } \\
\text { masih } \\
\text { sekitaran } \\
\text { orang } \\
\text { terdekat dan } \\
\text { belum luas }\end{array}$ & $\begin{array}{l}\text { Perluasan } \\
\text { pemasaran } \\
\text { dengan } \\
\text { system } \\
\text { online dan } \\
\text { juga offline } \\
\text { melalui } \\
\text { kegiatan } \\
\text { pelatihan } \\
\text { digital } \\
\text { marketing } \\
\text { teori dan } \\
\text { praktek }\end{array}$ \\
\hline
\end{tabular}




\begin{tabular}{|c|c|c|c|}
\hline 10. & $\begin{array}{c}\text { Penyus } \\
\text { unan } \\
\text { Propos } \\
\text { al bisnis }\end{array}$ & $\begin{array}{l}\text { Belum mahir } \\
\text { dalam } \\
\text { membuat } \\
\text { proposal } \\
\text { bisnis }\end{array}$ & $\begin{array}{l}\text { Penyusuna } \\
\text { n prosposal } \\
\text { bisnis yang } \\
\text { layak } \\
\text { diajukan } \\
\text { dengan } \\
\text { mengikuti } \\
\text { panduan } \\
\text { yang } \\
\text { tersedia. }\end{array}$ \\
\hline 11. & $\begin{array}{l}\text { Penyus } \\
\text { unan } \\
\text { laporan } \\
\text { keuang } \\
\text { an }\end{array}$ & $\begin{array}{l}\text { Penyusunan } \\
\text { laporan } \\
\text { keuangan } \\
\text { masih dalam } \\
\text { bentuk } \\
\text { sederhana } \\
\text { dan kurang } \\
\text { rapi dalam } \\
\text { administrasi } \\
\text { keuangan }\end{array}$ & $\begin{array}{l}\text { Diajarkan } \\
\text { materi } \\
\text { financial } \\
\text { literasi } \\
\text { untuk } \\
\text { mengatur } \\
\text { laporan } \\
\text { keuangan } \\
\text { menjadi } \\
\text { lebih rapi } \\
\text { serta } \\
\text { penyusunan } \\
\text { HPP yang } \\
\text { baik }\end{array}$ \\
\hline
\end{tabular}

Kegiatan PPK ini bermitra dengan Mini University Bank Indonesia Provinsi Kalimantan Timur yang turut berkontribusi sebagai narasumber dalam pelaksanaan kegiatan webinar, kegiatan pelatihan serta kunjungan studi lapang UMKM yang sudah maju sebagai binaan Bank Indonesia sebagai sarana pembelajaran tenant PPK di lapang.

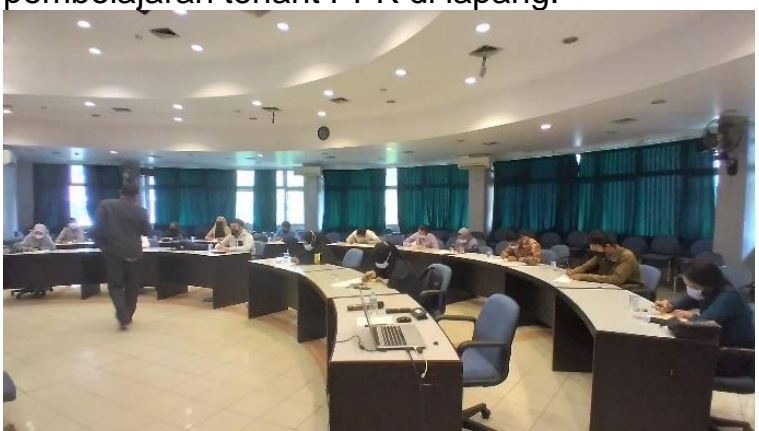

Gambar 1. Pelatihan Kewirausahaan

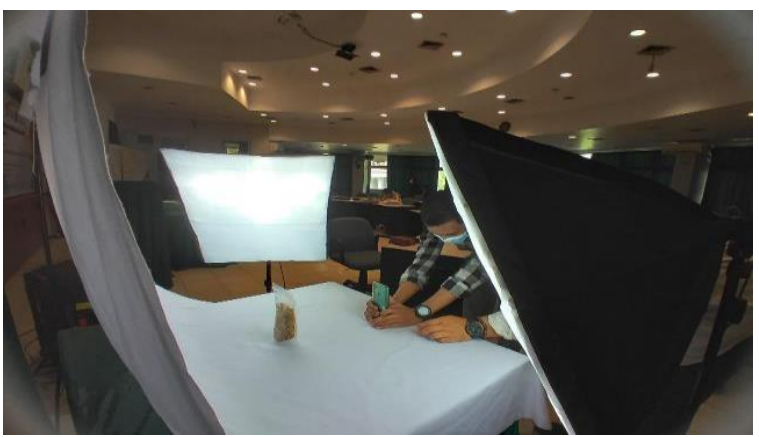

Gambar 2. Pelatihan Kewirausahaan

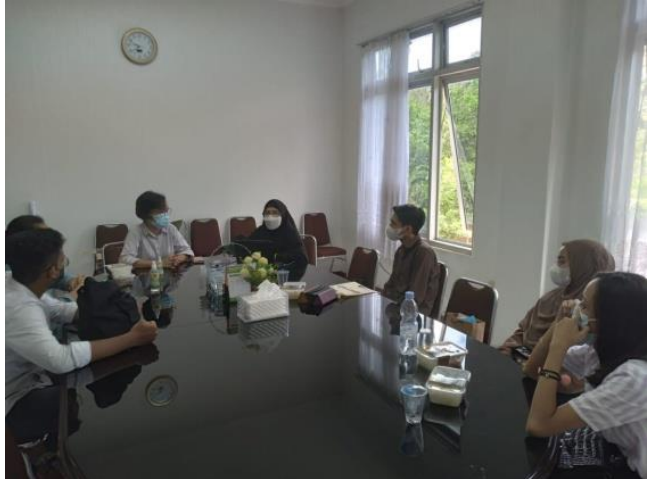

Gambar 3. Pendampingan Wirausaha Tenant



Gambar 4. Studi Lapang dan FGD UMKM

\section{SIMPULAN DAN SARAN \\ Simpulan}

Kegiatan PPK berjalan dengan baik dengan diikuti 20 orang calon tenant dari berbagai fakultas dari Fakultas Teknik, Fakultas Pertanian, Fakultas Kedokteran, Fakultas IImu keguruan dan Pendidikan, Fakultas IImu sosial dan Politik. Kegiatan PPK telah berjalan dengan baik yang menghasilkan wirausaha yang mandiri

\section{Saran}

Dilakukan expo secara virtual produk produk tenant PPK

\section{UCAPAN TERIMAKASIH}

Penulis mengucapkan terimakasih kepada Direktorat Riset dan Pengabdian masyarakat Kemendikbudristek atas Hibah pengabdian Kepada masyarakat tahun 2021.

\section{DAFTAR RUJUKAN}

Alma, Buchari. (2010). Kewirausahaan (edisi revisi). Bandung: CV Alfabeta

Haeruman, H. (2000). "Peningkatan Daya Saing UKM untuk Mendukung Program PEL". Makalah Seminar Peningkatan Daya Saing, Graha Sucofindo. Jakarta

Imron Rosyadi (2013) "Micro Small Enterprises Development Strategy Model Owned by Student Strategic Role Based" Prosiding Unsoed SCA 3.Purwokerto

Kuratko, D.F. \& Hodgetts, R.M. (2007). Entrepreneurship: Theory, Process, 
Practice (7th ed). Canada: Interactive Composition Corporation.

Timmons, Jeffry A. \& Spinelli, S., Jr. (2008). New Venture Creation. Kewirausahaan untuk Abad 21. Yogyakarta: Andi. (Buku asli New Venture Creation: Entrepreneurship for the 21st Century 6th ed.) 